\title{
FANCA Gene Amplification
}

National Cancer Institute

\section{Source}

National Cancer Institute. FANCA Gene Amplification. NCI Thesaurus. Code C131457.

A molecular genetic abnormality indicating the presence of multiple copies of the FANCA gene. 